\title{
A scheme for the identification of viridans streptococci
}

\author{
D. BEIGHTON, J. M. HARDIE* and R. A. WHILEY*
}

Hunterian Dental Research Unit and *Department of Oral Microbiology, London Hospital Medical College, Turner Street, Whitechapel, London E1 $2 A D$

\begin{abstract}
Summary. A collection of strains representing all the currently recognised species of oral or viridans streptococci (Streptococcus sanguis, $S$. parasanguis, $S$. gordonii, $S$. oralis, $S$. mitis, $S$. salivarius, $S$. vestibularis, $S$. anginosus, $S$. constellatus, $S$. intermedius, $S$. mutans and $S$. sobrinus) were tested for the production of a range of glycosidase activities with 4-methylumbelliferyllinked fluorogenic substrates, and for reactions in a range of conventional fermentation and hydrolytic tests. The resulting biochemical scheme, consisting of 14 tests, enabled the differentiation of all these species and distinguished three biotypes within $S$. sanguis. The scheme reported here represents an improvement over currently available schemes for the identification of viridans streptococci.
\end{abstract}

\section{Introduction}

The oral or viridans streptococci form a significant part of the normal flora of the human oral cavity and are associated with several disease conditions including dental caries, infective endocarditis and septicaemia, as well as purulent infections of oral and other sites. The identification of these streptococci has long been recognised as unsatisfactory, with the result that a significant proportion of fresh isolates remain unidentified. $^{1}$

In the 1970s, two biochemical schemes for the identification of viridans streptococci were published and subsequently widely adopted. The scheme of Colman and Williams ${ }^{2}$ recognised five species of viridans streptococci isolated mainly from the mouth (Streptococcus mutans, S. milleri, S. sanguis, S. salivarius and $S$. mitior) and became established mainly in European laboratories. The second scheme, devised by Facklam, ${ }^{3}$ was more widely used in the USA and differed in assigning strains classified by Colman and Williams $^{2}$ as $S$. sanguis and $S$. mitior to $S$. sanguis I and $S$. sanguis II or $S$. mitis, and also by dividing strains of $S$. milleri into $S$. anginosus-constellatus and $S$. $M G$-intermedius. These differences in both classification and nomenclature resulted in considerable confusion in the literature. ${ }^{4,5}$ Nevertheless, the scheme of Facklam, ${ }^{3}$ in particular, has formed the basis of several commercial identification kits. ${ }^{6}$

In more recent years, the classification of the viridans streptococci has been clarified by the application of whole genomic DNA-DNA hybridisation, DNA-ribosomal RNA (rRNA) hybridisation and rRNA sequencing techniques to the delineation of species and their natural (phylogenetic) relationships. $^{7-23}$

Received 2 Feb. 1991 ; accepted 9 April 1991.
Despite these improvements in our knowledge of the taxonomic relationships between streptococcal species, there has remained a lack of reliable phenetic tests with which to discriminate between these species and allow confident strain identification, particularly in the routine laboratory. ${ }^{17,18,24}$ This problem was recently addressed by Kilian et al., ${ }^{25}$ who employed chromogenic substrates for the detection of glycosidic hydrolases, peptidases, phosphatases, esterases and lipases, together with tests for the detection of $\operatorname{IgA}$ protease and neuraminidase (sialidase) activity as well as conventional tests for carbohydrate fermentation and hydrolysis tests. These authors proposed a scheme for the identification of $S$. gordonii, $S$. mitis, $S$. oralis, $S$. sanguis, $S$. salivarius, $S$. mutans and $S$. anginosus ( $S$. milleri-group). ${ }^{25}$ However, several of the more recently described species-S. vestibularis, ${ }^{21} S$. parasanguis ${ }^{20}$ and the three species within the $S$. milleri group ( $S$. anginosus, $S$. constellatus and $S$. intermedius) ${ }^{26}$-and $S$. sobrinus ${ }^{9}$ were not included.

We have reported previously identification schemes for human mutans streptococci ( $S$. mutans and $S$. sobrinus) ${ }^{27}$ and for the $S$. milleri-group. ${ }^{28}$ However, in the light of these taxonomic changes, we have assembled a collection of strains, representative of the other species of viridans streptococci, whose taxonomic position has been established by DNA-DNA hybridisation or by analysis of SDS-PAGE cell-protein profiles. ${ }^{29}$ The reactions of these strains have been used to develop a scheme that permits their identification.

\section{Materials and methods}

\section{Bacterial strains}

The bacteria used in this study are listed in table I. They were maintained at $-80^{\circ} \mathrm{C}$ in glycerol broth and 
Table I. List of bacterial strains used in this study

\begin{tabular}{|c|c|}
\hline Species & Strains \\
\hline S. parasanguis & 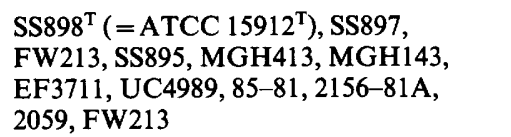 \\
\hline S. sanguis & 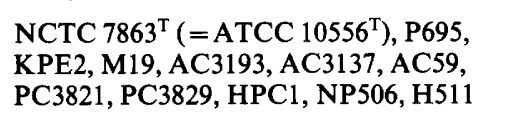 \\
\hline S. oralis & $\begin{array}{l}\text { LVG1 }^{\mathrm{T}}\left(=\text { NCTC } 11427^{\mathrm{T}}\right), \text { NCTC } 7864, \\
\text { M254, M524, PC1467, H362, OPA1, B } 88 \text {, } \\
\text { OS51, GDP1 }\end{array}$ \\
\hline S. gordonii & $\begin{array}{l}\text { NCTC } 7865^{\mathrm{T}} \text {, NCTC } 7868, \text { NCTC } 10231 \text {, } \\
\text { NCTC } 3165, \mathrm{H} 44, \mathrm{H} 730, \mathrm{M} 5 \text {, GPF } 1, \\
\text { F90A }\end{array}$ \\
\hline "Tufted fibril group" & CC5A, AK1R, CR3, CR311 \\
\hline S. mitis & $\begin{array}{l}\text { NS5 } 1^{\mathrm{T}}\left(=\text { NCTC } 12261^{\mathrm{T}}\right), \text { NCTC } 10712, \\
\text { PP53, HV } 51, \text { K208 }\end{array}$ \\
\hline S. vestibularis & $\begin{array}{l}\text { MM1 }^{\mathrm{T}}\left(=\text { NCTC } 12166^{\mathrm{T}}\right), \text { HV81, OP81, } \\
\text { LV71, JW3, AS2 }\end{array}$ \\
\hline S. salivarius & $\begin{array}{l}\text { NCTC } 8618^{\mathrm{T}}\left(=\text { ATCC } 19258^{\mathrm{T}}\right) \text {, NCTC } \\
8606, \text { ATCC } 9759, \text { A385, B128, B242, } \\
\text { H50, H53, GSS2, KPS1, M36, M236, } \\
\text { P511, T267 }\end{array}$ \\
\hline
\end{tabular}

ATCC, American Type Culture Collection; NCTC, National Collection of Type Cultures; ${ }^{\mathrm{T}}$, type strain.

routinely cultured on Columbia Agar (Oxoid) supplemented with horse blood $5 \% \mathrm{v} / \mathrm{v}$ and incubated anaerobically at $37^{\circ} \mathrm{C}$ for $1-2$ days.

In addition to the currently recognised viridans species, four strains of " $S$. sanguis with tufted fibrils" 30 (referred to here as the "tufted fibril group") were included as they have been shown by DNA-DNA hybridisation to represent an, as yet, unnamed species. $^{24}$

\section{Fermentation and enzyme tests}

The production of acid from amygdalin, arbutin, inulin, lactose, mannitol, melibiose, $N$-acetylglucosamine, raffinose and sorbitol, hydrolysis of aesculin, formation of ammonia from arginine and urea, and the production of $\mathrm{H}_{2} \mathrm{O}_{2}$ were determined as previously described. ${ }^{31}$ Briefly, carbohydrate fermentation reactions were determined with a basal medium composed of Purple Broth Base (Difco) $24 \mathrm{~g}$ and Thioglycollate medium without dextrose or indicator (Difco) $12 \mathrm{~g}$ with carbohydrates added at a concentration of $0.5 \% \mathrm{w} / \mathrm{v}$ before autoclaving. Bacteria were grown for $48 \mathrm{~h}$ in 4-ml volumes of Todd-Hewitt Broth (Oxoid) for inoculation in to these tests which, with the exception of urea hydrolysis and formation of $\mathrm{H}_{2} \mathrm{O}_{2}$, were set up in sterile, flat-bottomed microtitration trays fitted with individual lids (Sterilin); the test volumes were $c .200 \mu \mathrm{l}$ of medium and $c .50 \mu \mathrm{l}$ of culture. The inoculated microtitration trays were then incubated anaerobically for $24 \mathrm{~h}$ and the results were recorded. The production of specific glycosidic enzyme activities was determined as described by Whiley $e t$ $a l .^{28}$ with 4-methylumbelliferyl-linked substrates. The bacteria for these tests were grown anaerobically for $48 \mathrm{~h}$ on Columbia agar supplemented with horse blood $5 \% \mathrm{v} / \mathrm{v}$, removed from the plates with swabs and suspended in $1 \mathrm{ml}$ of $50 \mathrm{~mm}$ TES buffer (Sigma), $\mathrm{pH}$ $7 \cdot 5$, to an optical density (at $620 \mathrm{~nm}$ ) of $c .0 \cdot 1$. To $20 \mu 1$ of each substrate solution (made up in TES buffer at $100 \mu \mathrm{g} / \mathrm{ml}$ ), a single drop of the bacterial suspension was added. These tests were performed in non-sterile flat-bottomed microtitration trays; round-bottomed trays were difficult to view on an ultra-violet light box. Substrate hydrolysis was determined by measuring fluorescence on a Perkin Elmer fluorimeter after incubation for $3 \mathrm{~h}$ at $37^{\circ} \mathrm{C}$. Production of an enzyme activity was considered positive if there was an increase in fluorescence of 50 units, equivalent to c. $20 \mathrm{nmol}$ of substrate being degraded. Hydrolysis of this amount of substrate could also be readily visualised, as a distinct blue fluorescence, by placing the clear microtitration trays on an ultra-violet light box.

\section{Results}

The percentages of strains that gave positive reactions for each of the tests used in this study are shown in table II. $S$. parasanguis strains could be differentiated from $S$. sanguis and $S$. gordonii on the basis of $\beta$ - $N$-acetylgalactosaminidase, $\alpha$-glucosidase and $\alpha$-L-fucosidase activities and fermentation of inulin. S. oralis and some strains of $S$. mitis produced sialidase activity, but $\beta$ - $N$-acetylglucosaminidase activity distinguished between these two species. The "tufted fibril group" were all $\alpha$-L-fucosidase-positive and $\beta$-glucosidase-negative. Strains of $S$. vestibularis and $S$. salivarius stood apart because virtually all were $\alpha$-arabinosidase-positive. Differentiation between $S$. vestibularis and $S$. salivarius rested upon $\beta$-D-fucosidase and $\beta$-glucosidase activities, the fermentation of inulin and raffinose, and the production of $\mathrm{H}_{2} \mathrm{O}_{2}$.

With the exception of $S$. salivarius, in which strains fermented raffinose more frequently than melibiose, and $S$. vestibularis which fermented neither carbohydrate, there was some biochemical heterogeneity because of the presence of strains that fermented both melibiose and raffinose and produced $\alpha$-galactosidase or that gave uniformly negative results in each of these three tests. Considerable heterogeneity was observed within strains of $S$. sanguis and $S$. vestibularis: three biotypes of $S$. sanguis were differentiated on the basis of the production of $\beta$-D-fucosidase and $\alpha$-galactosidase and fermentation of amygdalin, melibiose and raffinose, as well as hydrolysis of aesculin (table III). Strains of $S$. vestibularis formed two biotypes (each of three strains) which were differentiated on the basis of fermentation of amygdalin and $\mathrm{N}$-acetylglucosamine, and hydrolysis of aesculin.

In table IV, a scheme is presented for the identification of the viridans streptococcal species including 
Table II. Percentages of strains in each species that gave positive reactions in tests

\begin{tabular}{|c|c|c|c|c|c|c|c|c|}
\hline \multirow{2}{*}{ Enzyme activity } & \multicolumn{8}{|c|}{ Streptococcal species } \\
\hline & A & B & $\mathrm{C}$ & $\mathrm{D}$ & E & F & G & $\mathbf{H}$ \\
\hline$\beta$-D-fucosidase & 73 & 18 & 0 & 0 & 0 & 0 & 0 & 71 \\
\hline$\beta-N$-acetylgal-dase & 0 & 100 & 78 & 100 & 100 & 0 & 0 & 0 \\
\hline sialidase & 0 & 0 & 0 & 0 & 100 & 25 & 0 & 0 \\
\hline$\alpha$-L-fucosidase & 0 & 27 & 100 & 100 & 0 & 0 & 0 & 0 \\
\hline$\beta$-N-acetylglu-dase & 33 & 100 & 100 & 100 & 100 & 0 & 0 & 0 \\
\hline$\alpha$-glucosidase & 0 & 100 & 22 & 0 & 100 & 100 & 66 & 36 \\
\hline$\beta$-glucosidase & 58 & 27 & 100 & 0 & 0 & 0 & 0 & 64 \\
\hline$\alpha$-galactosidase & 58 & 91 & 11 & 0 & 36 & 80 & 0 & 14 \\
\hline$\alpha$-arabinosidase & 0 & 18 & 0 & 0 & 0 & 0 & 100 & 93 \\
\hline$\beta$-galactosidase & 33 & 100 & 44 & 25 & 64 & 40 & 100 & 86 \\
\hline \multicolumn{9}{|l|}{ Acid produced from: } \\
\hline $\begin{array}{l}\text { amygdalin } \\
\text { arbutin }\end{array}$ & $\begin{array}{l}42 \\
83\end{array}$ & $\begin{array}{l}18 \\
45\end{array}$ & $\begin{array}{l}100 \\
100\end{array}$ & $\begin{array}{r}0 \\
100\end{array}$ & $\begin{array}{l}y \\
9\end{array}$ & 0 & $\begin{array}{l}50 \\
33\end{array}$ & $\begin{array}{l}29 \\
93\end{array}$ \\
\hline inulin & 33 & 0 & 100 & 0 & 0 & 40 & 0 & 79 \\
\hline lactose & 100 & 100 & 100 & 75 & 100 & 80 & 66 & 93 \\
\hline mannitol & 0 & 0 & 0 & 0 & 0 & 0 & 0 & 0 \\
\hline melibiose & 75 & 82 & 11 & 0 & 55 & 100 & 0 & 7 \\
\hline $\mathrm{N}$-acetylglucosamine & 100 & 100 & 100 & 100 & 100 & 100 & 50 & 29 \\
\hline raffinose & 75 & 82 & 11 & 0 & 55 & 100 & 0 & 79 \\
\hline sorbitol & 42 & 9 & 0 & 0 & 0 & 0 & 0 & 0 \\
\hline \multicolumn{9}{|l|}{ Hydrolysis of: } \\
\hline aesculin & 75 & 36 & 100 & 0 & 18 & 0 & 50 & 93 \\
\hline arginine & 100 & 100 & 100 & 75 & 0 & 0 & 0 & 0 \\
\hline urea & 0 & 0 & 0 & 0 & 0 & 0 & 100 & 57 \\
\hline $\mathrm{H}_{2} \mathrm{O}_{2}$ produced & 100 & 91 & 100 & 100 & 100 & 100 & 83 & 14 \\
\hline Number of strains & 12 & 11 & 9 & 4 & 11 & 5 & 6 & 14 \\
\hline
\end{tabular}

A, S. sanguis; B, S. parasanguis; C, S. gordonii; D, "tufted fibril group"; E, S. oralis; F, S. mitis; G, S. vestibularis; H, $S$. salivarius; $\beta$ - $N$-acetylgal-dase $=\beta-N$-acetylgalactosaminidase $; \beta$ - $N$-acetylglu-dase $=\beta$ - $N$-acetylglucosaminidase.

$S$. intermedius, $S$. constellatus, $S$. anginosus, $S$. mutans and $S$. sobrinus whose reactions in these tests have been reported previously. ${ }^{27,28}$

\section{Discussion}

The recent taxonomic proposals for the viridans streptococci have produced a situation in which more species have been described than, in practice, can be differentiated reliably by simple biochemical tests, ${ }^{17,18,24}$ including those incorporated into commercially available identification kits. These proposals include the descriptions of new species-S. gordonii, ${ }^{25}$ $S$. vestibularis ${ }^{21}$ and $S$. parasanguis ${ }^{20}$-as well as emended descriptions of $S$. oralis, $S$. sanguis and $S$. mitis $^{25}$ and the reclassification of strains currently recognised as $S$. anginosus (the $S$. milleri group) into three separate species, $S$. anginosus, $S$. constellatus and $S$. intermedius for which emended descriptions have also been reported. ${ }^{26}$

Our purpose was to develop a scheme that would permit the identification of all these currently recognised viridans streptococcal species. To produce a reliable scheme it was necessary to examine only strains whose taxonomic position was known from DNA-DNA hybridization and SDS-PAGE studies.

New phenotypic tests, in addition to the traditional tests used in previous schemes for the identification of viridans streptococci, were thought necessary. Previously, Kilian et al. ${ }^{25}$ had introduced a fluorogenic test for the demonstration of neuraminidase (sialidase) activity amongst viridans streptococci and found that $S$. oralis and $S$. mitis strains gave positive results. We subsequently confirmed these observations with a rapid $(3 \mathrm{~h})$ test and also demonstrated that $S$. intermedius strains, isolated primarily from dental plaque and from brain and liver abscesses, were also sialidase positive. $^{32}$

Here we have used a number of other fluorogenic substrates for the demonstration of glycosidase activity; such substrates were used previously to provide phenotypic characteristics for the differentiation of $S$. anginosus, $S$. constellatus and $S$. intermedius in the $S$. milleri group. ${ }^{28}$ However, it should be noted that Kilian et al. ${ }^{25}$ demonstrated that the choice of substrate can influence the detection of glycosidase activities amongst streptococci. Thus, tests for the production of $\beta$-D-galactosidase and $\beta$-D-glucosidase gave different results depending upon the substrates (naphthol or nitrophenol derivatives) used. It follows, therefore, that the glycosidase activities detected with 4-methylumbelliferone derivatives may not necessarily agree with those demonstrable with other types of synthetic glycosidase substrates.

In the majority of schemes for the identification of 
Table III. Differentiation of strains of $S$. sanguis into biotypes $(1,2$ and 3$)$ and the percentage of strains that gave positive reactions in tests

\begin{tabular}{|c|c|c|c|}
\hline \multirow{2}{*}{ Enzyme activity } & \multicolumn{3}{|c|}{$S$. sanguis biotype } \\
\hline & 1 & & 3 \\
\hline$\beta$-D-fucosidase & 0 & 100 & 66 \\
\hline$\beta$-N-acetylgal-dase & 0 & 0 & 0 \\
\hline sialidase & 0 & 0 & 0 \\
\hline$\alpha$-L-fucosidase & 0 & 0 & 0 \\
\hline$\beta$-N-acetylglu-dase & 0 & 20 & 100 \\
\hline$\alpha$-glucosidase & 0 & 0 & 0 \\
\hline$\beta$-glucosidase & 25 & 100 & 33 \\
\hline$\alpha$-galactosidase & 50 & 100 & 0 \\
\hline$\alpha$-arabinosidase & 0 & 0 & 0 \\
\hline$\beta$-galactosidase & 0 & 20 & 100 \\
\hline \multicolumn{4}{|l|}{ Acid produced from: } \\
\hline $\begin{array}{l}\text { amygdalin } \\
\text { arbutin }\end{array}$ & $\begin{array}{r}0 \\
100\end{array}$ & 100 & $\begin{array}{r}0 \\
33\end{array}$ \\
\hline $\begin{array}{l}\text { arbutin } \\
\text { inulin }\end{array}$ & $\begin{array}{r}100 \\
50\end{array}$ & 20 & 33 \\
\hline $\begin{array}{l}\text { inulin } \\
\text { lactose }\end{array}$ & 100 & 100 & 100 \\
\hline $\begin{array}{l}\text { lactose } \\
\text { mannitol }\end{array}$ & 0 & 0 & 0 \\
\hline melibiose & 100 & 60 & 0 \\
\hline $\mathrm{N}$-acetylglucosamine & 100 & 100 & 100 \\
\hline raffinose & 100 & 100 & 0 \\
\hline sorbitol & 25 & 80 & 0 \\
\hline \multicolumn{4}{|l|}{ Hydrolysis of: } \\
\hline aesculin & 100 & 100 & 0 \\
\hline arginine & 100 & 100 & 100 \\
\hline urea & 0 & 0 & 0 \\
\hline $\mathrm{H}_{2} \mathrm{O}_{2}$ produced & 100 & 100 & 100 \\
\hline Number of strains & 4 & 5 & 3 \\
\hline
\end{tabular}

$\beta$ - $N$-acetylgal-dase $=\beta$ - $N$-acetylgalactosaminidase;

$\beta$ - $N$-acetylglu-dase $=\beta$ - $N$-acetylglucosaminidase

viridans streptococci, tests for polymer production from sucrose and the formation of acetylmethylcarbinol from glucose (VP test) are included. ${ }^{2,25}$ In addition, the ability of viridans streptococci to bind salivary $\alpha$ amylase has been shown to be a useful discriminating test. $^{33}$ These reactions are not required for the identification of streptococci in the scheme described here. However, it would be advantageous to examine streptococci from dental plaque for the production of glucan on a sucrose-containing medium where glucan production, in conjunction with typical colonial morphology, ${ }^{1}$ might be useful for the identification of $S$. mutans and $S$. sobrinus.

Several authors have proposed fermentation of one or both of raffinose and melibiose as distinctive tests; Shklair and Keene ${ }^{34}$ used fermentation of these two sugars to differentiate between serotype $c$ and serotype $e$ strains of $S$. mutans and Kilian et al. ${ }^{25}$ formed biotypes of $S$. sanguis and $S$. gordonii based upon the ability of strains to ferment these two sugars: $S$. sanguis biotype 1 ferments both sugars whereas biotype 4 ferments neither, with all other test results being the same. We found that $S$. gordonii strain F90A fermented both melibiose and raffinose whereas all other $S$. gordonii strains gave negative results in these two tests. However, Kilian et al. ${ }^{25}$ separated $S$. gordonii biotype 1 (which includes strain F90A) from biotypes 2 and 3 solely on the basis of raffinose and melibiose fementation. In this study we found virtual concordance between the results of these two tests; if a strain fermented melibiose, it also fermented raffinose, the major exception being amongst strains of $S$. salivarius.

Recent genetic studies ${ }^{35,36}$ on the fermentation of these sugars by $S$. mutans may be useful in explaining these observations. The two sugars are related, raffinose being a trisaccharide (galactose-glucosefructose) and melibiose a disaccharide (galactoseglucose); both are substrates for $\alpha$-galactosidase. Absence of $\alpha$-galactosidase results in a melibiosenegative phenotype and reduced or delayed fermentation of raffinose. Residual fermentation can occur

Table IV. Scheme for the identification of viridans streptococci

\begin{tabular}{|c|c|c|c|c|c|c|c|c|c|c|c|c|c|c|c|}
\hline \multirow{2}{*}{ Enzyme activity } & \multicolumn{15}{|c|}{ Streptococcal species } \\
\hline & Al & $\mathrm{A} 2$ & $\mathrm{~A} 3$ & B & $\mathrm{C}$ & D & $\mathrm{E}$ & $\mathrm{F}$ & $\mathrm{G}$ & $\mathbf{H}$ & I & $\mathbf{J}$ & K & $\mathrm{L}$ & M \\
\hline$\beta$-D-fucosidase & - & + & $\mathrm{d}$ & $\mathrm{d}$ & - & - & - & - & - & d & + & - & - & - & - \\
\hline$\beta$-N-acetylgal-dase & - & - & - & + & $\mathrm{d}$ & + & + & - & - & - & + & - & - & - & - \\
\hline sialidase & - & - & - & - & - & - & + & $\mathrm{d}$ & - & - & + & - & - & - & - \\
\hline$\alpha$-L-fucosidase & - & - & - & $\mathrm{d}$ & + & + & - & - & - & - & - & - & - & - & - \\
\hline$\beta$-N-acetylglu-dase & - & $\mathrm{d}$ & + & + & + & + & + & - & - & - & + & - & - & - & - \\
\hline$\alpha$-glucosidase & - & - & - & + & $\mathrm{d}$ & - & + & + & $\mathrm{d}$ & d & + & + & - & + & + \\
\hline$\beta$-glucosidase & $\mathrm{d}$ & + & d & $\mathrm{d}$ & + & - & - & - & - & d & $\mathrm{d}$ & - & + & + & - \\
\hline$\alpha$-arabinosidase & - & - & - & $\mathrm{d}$ & - & - & - & - & + & + & - & - & - & - & - \\
\hline $\begin{array}{l}\text { Acid produced from: } \\
\text { amygdalin }\end{array}$ & & & & & & & & & & & & & & & \\
\hline $\begin{array}{l}\text { amygdalin } \\
\text { inulin }\end{array}$ & $\overline{\mathrm{d}}$ & $\begin{array}{l}+ \\
\mathrm{d}\end{array}$ & $\overline{\mathrm{d}}$ & $\frac{\mathrm{d}}{-}$ & $\begin{array}{l}+ \\
+\end{array}$ & - & - & $\overline{\mathrm{d}}$ & $\begin{array}{l}\mathrm{d} \\
-\end{array}$ & $\begin{array}{l}\mathrm{d} \\
\mathrm{d}\end{array}$ & d & $\begin{array}{l}\mathrm{d} \\
-\end{array}$ & $\begin{array}{l}+ \\
-\end{array}$ & $\begin{array}{l}+ \\
+\end{array}$ & - \\
\hline mannitol & - & - & - & - & - & - & - & - & - & - & - & - & - & + & + \\
\hline$N$-acetylglucosamine & + & + & + & + & + & + & + & + & + & + & + & d & d & + & - \\
\hline raffinose & + & + & - & $\mathrm{d}$ & - & - & $\mathrm{d}$ & + & - & d & - & - & $\mathrm{d}$ & + & - \\
\hline $\begin{array}{l}\text { Hydrolysis of: } \\
\text { arginine }\end{array}$ & + & + & + & + & + & d & - & - & - & - & + & + & + & - & - \\
\hline
\end{tabular}

A1, A2 and A3, S. sanguis biotypes 1, 2 and $3 ; \mathrm{B}, S$. parasanguis; C, S. gordonii; D, "tufted fibril group"; E, S. oralis; F, S. mitis; G, $S$. vestibularis; H, S. salivarius; I, S. intermedius; J, S. constellatus; K, S. anginosus; L, S. mutans; M, S. sobrinus (data for species I to M from Whiley et al., ${ }^{28}$ and Beighton $e t$ al. $^{27}$ ).

,$+>85 \%$ of strains positive; $d, 15-85 \%$ of strains positive;,$-<15 \%$ of strains positive. 
because raffinose is also a substrate for fructosyltransferase which is produced by both the mutans streptococci and $S$. salivarius but not by the other viridans streptococcal species. Thus, it is apparent that melibiose and raffinose fermentation do not constitute two independent tests, at least in $S$. mutans and probably in most other viridans streptococci. Therefore, with the exception of $S$. sanguis, we have not described biotypes within the species studied here which rely solely upon differences in melibiose and raffinose fermentation. Three biotypes for $S$. sanguis are suggested rather than the four of Kilian et al., ${ }^{25}$ a

\section{References}

1. Hardie JM, Marsh PD. Oral streptococci. In: Skinner FA, Quesnel LB (eds) Streptococci. (Society for Applied Bacteriology Symposium Series No. 7.) London, Academic Press. 1978: 380-383.

2. Colman G, Williams REO. Taxonomy of some human viridans streptococci. In: Wannamaker LW, Matsen JM (eds) Streptococci and streptococcal diseases. London, Academic Press. 1972: 281-299.

3. Facklam, RR. Physiological differentiation of viridans streptococci. J Clin Microbiol 1977; 5: 184-201.

4. Facklam RR. The major differences in the American and British Streptococcus taxonomy schemes with special reference to Streptococcus milleri. Eur J Clin Microbiol 1984 3: $91-93$

5. Hardie JM. Oral streptococci. In: Sneath PHA, Mair NS Sharpe ME (eds) Bergey's Manual of systematic bacteriology, vol 2. Baltimore, Williams and Wilkins. 1986: 1054 1063.

6. Peterson EM, Shigei JT, Woolard A, De la Maza LM Identification of viridans streptococci by three commercial systems. Am J Clin Pathol 1988; 90: 87-91.

7. Beighton D, Hayday H, Russell RRB, Whiley RA. Streptococcus macacae sp. nov. from dental plaque of monkeys (Macaca fascicularis). Int J Syst Bacteriol 1984; 34: 332-335.

8. Coykendall AL. Proposal to elevate the subspecies of Streptococcus mutans to species status, based on their molecular composition. Int J Syst Bacteriol 1977; 27: 26-30.

9. Coykendall AL. Streptococcus sobrinus nom. rev. and Streptococcus ferus nom. rev.: habitat of these and other mutans streptococci. Int J Syst Bacteriol 1983; 33: 883-885.

10. Coykendall AL, Munzenmaier AJ. Deoxyribonucleic acid base sequence studies on glucan-producing and glucan-negative strains of Streptococcus mitior. Int J Syst Bacteriol 1978; 28 $511-515$.

11. Coykendall AL, Specht PA. DNA base sequence homologies among strains of Streptococcus sanguis. J Gen Microbiol 1975; 91: 92-98.

12. Coykendall AL, Wesbecher PM. Genetic relationships among some "viridans" streptococci. In: Lutticken R (ed) 10th Lancefield international symposium on streptococci and streptococcal diseases (in press).

13. Farrow JAE, Collins MD. DNA base composition, DNADNA homology and long-chain fatty acid studies on Streptococcus thermophilus and Streptococcus salivarius. J Gen Microbiol 1984; 130: 357-362.

14. Kilpper-Bälz R, Williams BL, Lütticken R, Schleifer KH Relatedness of "Streptococcus milleri" with Streptococcus anginosus and Streptococcus constellatus. Syst Appl Microbiol $1984 ; 5: 494-500$

15. Kilpper-Bälz, R, Wenzig P, Schleifer KH. Molecular relationships and classification of some viridans streptococci as Streptococcus oralis and emended description of Streptococcus oralis (Bridge and Sneath 1982). Int J Syst Bacteriol $1985 ; 35: 482-488$

16. Ludwig W, Seewaldt E, Kilpper-Bälz R et al. The phylogenetic position of Streptococcus and Enterococcus. J Gen Microbio $1985 ; 131$ : $543-551$. result, no doubt, of the use of different phenotypic tests and the range of isolates employed in the two studies.

The set of phenotypic tests used here enables representatives of all the currently reported human viridans streptococci to be distinguished. It must be recognised, however, that the number of strains of each species available for study, whose identity has been verified on the basis of other taxonomic criteria, is relatively small so that as more validated strains are examined, further heterogeneity may be revealed.

This work was supported in part by MRC grant GB8704557.

17. Schleifer KH, Kilpper-Bälz R. Molecular and chemotaxonomic approaches to the classification of streptococci, enterococci and lactococci : a review. Syst Appl Microbiol 1987; 10: 119.

18. Schmidhuber S, Kilpper-Bälz R, Schleifer KH. A taxonomic study of Streptococcus mitis, S. oralis, and S. sanguis. Syst Appl Microbiol 1987; 10: 74-77.

19. Welborn PP, Hadley WK, Newbrun E, Yajko DM. Characterization of strains of viridans streptococci by deoxyribonucleic acid hybridization and physiological tests. Int J Syst Bacteriol 1983; 33: 293-299.

20. Whiley RA, Fraser HY, Douglas CWI, Hardie JM, Williams AM, Collins MD. Streptococcus parasanguis sp. nov., an atypical viridans streptococcus from human clinical specimens. FEMS Microbiol Lett 1990; 68: 115-122.

21. Whiley RA, Hardie JM. Streptococcus vestibularis $\mathrm{sp}$. nov. from the human oral cavity. Int J Syst Bacteriol 1988; 38: 335339.

22. Whiley RA, Hardie JM. DNA-DNA hybridization studies and phenotypic characteristics of strains within the "Streptococcus milleri group". J Gen Microbiol 1989; 135: 26232633

23. Whiley RA, Russell RRB, Hardie JM, Beighton D. Streptococcus downei sp. nov. for strains previously described as Streptococcus mutans serotype h. Int J Syst Bacteriol 1988 38: $25-29$.

24. Coykendall AL. Classification and identification of the viridans streptococci. Clin Microbiol Rev 1989; 2 : 315-328.

25. Kilian M, Mikkelsen L, Henrichsen J. Taxonomic study of viridans streptococci; description of Streptococcus gordoni sp. nov. and emended descriptions of Streptococcus sanguis (White and Niven 1946), Streptococcus oralis (Bridge and Sneath, 1982) and Streptococcus mitis (Andrewes and Horder, 1906). Int J Syst Bacteriol 1989; 39: 471-484.

26. Whiley RA, Beighton D. Emended descriptions and recognition of Streptococcus constellatus, Streptococcus intermedius, and Streptococcus anginosus as distinct species. Int $J$ Syst Bacteriol 1991; 41 : 1-5.

27. Beighton D, Russell RRB, Whiley RA. A simple biochemica scheme for the differentiation of Streptococcus mutans and Streptococcus sobrinus. Caries Res 1991 ; 25 : 174-178.

28. Whiley RA, Fraser H, Hardie JM, Beighton D. Phenotypic differentiation of Streptococcus intermedius, Streptococcus constellatus and Streptococcus anginosus within the "Streptococcus milleri group”. J Clin Microbiol 1990; 28: 1497 1501 .

29. Whiley RA. A taxonomic study of oral streptococci. PhD thesis, London University, 1987.

30. Handley PS, Carter PL, Wyatt JE, Hesketh LM. Surface structures (peritrichous fibrils and tufts of fibrils) found on Streptococcus sanguis strains may be related to their ability to coaggregate with other oral genera. Infect Immun 1985; 47: 217-227.

31. Beighton D, Russell RRB, Hayday H. The isolation and characterization of Streptococcus mutans serotype $h$ from dental plaque of monkeys (Macaca fascicularis). J Gen Microbiol 1981; 124: 271-279.

32. Beighton D, Whiley RA. Sialidase activity of the "Streptococcus 
milleri group" and other viridans group streptococci. J Clin Microbiol 1990; 28: 1431-1433.

33. Douglas CWI, Pease AA, Whiley RA. Amylase-binding as a discriminator among oral streptococci. FEMS Microbiol Lett 1990; 66: 193-198.

34. Shklair IL, Keene HJ. A biochemical scheme for the separation of the five varieties of Streptococcus mutans. Arch Oral Biol $1974 ; 19$ : 1079-1081.
35. Aduse-Opoku J, Tao L, Ferretti JJ, Russell RRB. Biochemical and genetic analysis of Streptococcus mutans $\alpha$-galactosidase. J Gen Microbiol 1991; 137 : 737-764.

36. Russell RRB, Aduse-Opoku J, Tao L, Ferretti JJ. A binding protein-dependent transport system in Streptococcus mutans. In: Dunny G, Cleary P, McKay L (eds) Genetics and molecular biology of streptococci. Washington, American Society for Microbiology (in press). 